\title{
The Cytogenetic Basis of Human Infertility: A Review
}

\author{
Bheem Prasad $^{1 *}$ and Richa Jain ${ }^{2}$ \\ ${ }^{1}$ Department of Anatomy, All India Institute of Medical Sciences, Patna, Bihar-801505, India. \\ ${ }^{2}$ Department of Biochemistry and Genetics, Barkatullah University, Bhopal, M.P.-462026 India.
}

\begin{abstract}
Infertility resulting in humans has evoked considerable legal, medical and social interests. Infertility remains a major public health problem. Epidemiological studies reveal that genetic and environmental factors are responsible for infertility. As an estimate nearly $15-20 \%$ of couples have difficulty or is unable to conceive. Infertility is multi-factorial, but primarily it is because of male factor, female factor or a combination of both. Infertility can be hormonal, related to age, obesity, and infectious diseases, psychological or genetic. The genetic causes of infertility can be $Y$ chromosome deletion, single gene disorder, multi-factorial causes and chromosomal abnormalities. The incidence of autosomal chromosome abnormalities is 1.1 to $7.2 \%$ in infertile men, about $3 \%$ in the azoospermia group and up to $10.2 \%$ in the oligozoospermia group. Genetic research on infertility aims to correlating clinical consequences and genotype.
\end{abstract}

Key words: azoospermia, chromosomal aberrations, cytogenetics, infertility, syndromes, Y chromosome microdeletion.

\section{Introduction:}

Infertility is the most significant human health problem of the reproductive years. Infertility is described as failure to conceive after one year of unprotected intercourse ${ }^{1}$. The World Health Organization has described "infertility" as a health problem of global concern, one in seven couples experience infertility ${ }^{2}$. Shah et al. have also reported that one in every six couples wishing to start a family fall into this category ${ }^{3}$.

The prevalence of infertility is reported to be $10-15 \%$ worldwide. It is estimated that infertility affects nearly 50 to 80 million people around the world ${ }^{4}$. Currently 8-10 million infertile couples are estimated to be in India. The recent National Family Health Survey estimated childlessness as $2.4 \%$ of currently married women over 40 years of age in India ${ }^{5}$.

Primary and secondary infertility rates have been reported as $3 \%$ and $8 \%$, respectively ${ }^{6}$. A village level study conducted in the state of Maharashtra, India revealed infertility in the range between 6 to 7 per cent $^{7}$. In other states such of Haryana, Rajasthan, Madhya Pradesh, Punjab, Karnataka, Arunachal Pradesh and Tamilnadu have $2.25 \%, 3.57 \%, 4.23 \%, 4.93 \%, 6.73 \%, 8.72 \%$ and $10.92 \%$ childless couples respectively ${ }^{8}$. In the same study, $6 \%$ of male infertility and $14 \%$ of ovarian failure have been reported due to chromosomal abnormalities.

Infertility is multi factorial, but mainly it is because of male or female factors or a combination of both. Infertility can be hormonal, related to age, exercise, obesity or infectious diseases. It can be immunological, psychological, result from surgery or blockage or may be associated with defined abnormalities in the gametes. The most common causes of infertility are simply 'unexplained' and these account for about $20 \%$ of such couples ${ }^{9}$.

\section{Chromosomal Abnormalities:}

The chromosomal abnormalities found in infertile couples are numerical or structural. Gianotten et al., reported that over 4,000 genes are involved in the control of human spermatogenesis ${ }^{10}$.

\section{Numerical abnormalities}

1) Klinfelter's syndrome (47, XXY): Klinfelter's syndrome is found in approximately 1 in 1,000 males and due to non-disjunction of the $\mathrm{X}$ chromosome during meiosis. This syndrome is generally associated with the karyotype 47, XXY, which can be in all cells or in mosaic form. There are various extents of spermatogenetic failure, but males are generally sterile $\mathrm{e}^{3,11,12}$.

The gonadal defect in XXY male seems to be related to germ cell survival and sex chromosome constitution. It is through that the testicular atrophy seen in patients with Klienfelter's syndrome is due to failure of the germ cells, containing two X chromosomes (instead of one) to survive ${ }^{13}$. Beside this, the spermatogenic picture of XYY men shows a great diversity, ranging from severe impairment to apparent normalcy ${ }^{14}$. Other sexual numerical changes mainly involved other types of Klienfelter mosaics (45 X/47, XYY; 46, XY/47, $\mathrm{XXY} / 48, \mathrm{XXXY}$ ) and 47, XYY males. These changes were seen in azoospermic and oligozoospermic males ${ }^{15}$. 
2) 47, XYY males: $47, \mathrm{XYY}$ syndrome is found in approximately one in 1,000 male births. This syndrome arises due to non disjunction of the Y chromosome in paternal meiotic II. In 47, XYY male causes an aberrant hormonal balance in the gonadal environment which affects the normal function of human chorionic gonadotrophin ${ }^{16}$. Inclusion of extra sex chromosome (47, XYY) has been reported by May et al., Hassold et al. and Jacobs et al. $17,18,19$.

3) Turner syndrome: $\mathrm{A}$ loss of $\mathrm{X}$ chromosome $(45, \mathrm{X})$ is the characteristic karyotype of Turner syndrome. Frequency of Turner syndrome is one in 5,000 to one in $10,000^{20}$. Loss of chromosomes (X) resulting in numerical changes may be due to non-disjunction of chromosomes during gametogenesis. Due to non disjunction there is a possibility that a particular pair of chromosomes is transmitted to a gamete or it may be lost. There can be error in the gametogenesis due to the accumulation of mutations which might have taken place during the life span of an individual. These mutations are likely to be more in persons with advanced age.

4) 47, XXX: The frequency of 47, XXX is one in 1,000 females and $95 \%$ of cases the extra X chromosome is maternal origin. Most these females are normal height, weight and mental function and fertile but have an early onset of menopause at about age of 30 years compared with the average of about age of 50 years ${ }^{17}$.

\section{5) Down syndrome (Trisomy 21):}

Trisomy 21 is the most common cause of mental retardation, sexual dysfunction in humans. Affected females in rare cases can reproduce, however, most if not all, affected males are sterile, and the phenotype included spermatogenic arrest, reduction in the number of germ cells and bronchial tubes ${ }^{21}$.

\section{II) Structural abnormalities:}

1) Translocation: Robertsonian translocations are among the foremost common balanced structural rearrangements seen within the general population with a frequency in newborn surveys of regarding one in $1,000^{22}$. Tharapel et al. reported that an approximately seven fold excess of Robertsonian heterozygotes in infertile couples ${ }^{23}$. In autosome-autosome translocation, reduce fertility is mediated by the fact that the translocated chromosomes, in order to progress through meiosis, need to synapse through a pairing $\operatorname{cross}^{24,25}$.

The most common Robertsonian translocation observed in infertile males is $t(13 \mathrm{q} 14 \mathrm{q})$. Meiotic studies of infertile carriers of $t(13 q 14 q)$ and $t(14: 21)$ reveal abnormal behavior of the rearranged autosomes in meiosis during spermatogenesis causing infertility ${ }^{3,26,27}$.

2) Inversion: An inversion happens when a solitary chromosome experiences two breaks and is reconstituted with the fragment between the breaks inverted. The result of inversion is for the offspring, a carrier of either kind of inversion is at risk of producing abnormal gamete.

The most widely recognized reversal is 46, XY, inv (9) (p11q13) in oligozoospermic infertile male. Nemeth et al.reported an infertile man with a Klinefelter like phenotype having an $\mathrm{X}$ inversion with $46, \mathrm{Y}, \operatorname{inv}(\mathrm{X})$ $(\mathrm{q} 12 \mathrm{q} 25)^{28}$.

Dar et al.reported that a woman had dysgenesis with primary amenorrhea and she had a de novo inv (X) (q13 q24) ${ }^{29}$. Pericentric inversion of chromosome $1,3,5,6$ and 10 are related to abnormal sperm production in infertile men.

3. Marker chromosome: Marker chromosome is very small, unidentified chromosome. Marker chromosomes are additional chromosomes that are not effectively recognized by typical cytogenetic methods. Marker chromosome is occasionally seen in chromosome preparation, frequently in a mosaic state. Chromosome banding it is difficult to characterize marker chromosome. Carriers of marker chromosomes are at risk of infertility because of meiotic arrest and instability ${ }^{25}$.

Table I: Cytogenetic studies in different infertile couples.

\begin{tabular}{|l|l|l|l|l|l|l|}
\hline S. No. & Author & Year & $\begin{array}{l}\text { Male } \\
\text { karyotype }\end{array}$ & $\begin{array}{l}\text { Female } \\
\text { Karyotype }\end{array}$ & $\begin{array}{l}\text { Abnormal } \\
\text { karyotype in } \\
\text { males (\%) }\end{array}$ & $\begin{array}{l}\text { Abnormal } \\
\text { karyotype in } \\
\text { females (\%) }\end{array}$ \\
\hline 1. & Hens et al. $^{30}$ & 1988 & 500 & 500 & 0.8 & 1.8 \\
\hline 2. & Lange et al. $^{32}$ & 1990 & 72 & 72 & 2.8 & 15.3 \\
\hline 3. & Baschatt et al. $^{33}$ & 1996 & 32 & -- & 6.2 & -- \\
\hline 4. & Peschka et al. $^{34}$ & 1996 & 200 & 200 & 3.0 & 3.0 \\
\hline 5. & Testart et al. $^{35}$ & 1996 & 261 & 261 & 4.2 & 1.1 \\
\hline 6. & Mau et al. $^{36}$ & 1997 & 150 & 150 & 12.0 & 6.0 \\
\hline 7. & Montag et al. $^{37}$ & 1997 & 434 & 434 & 3.7 & 3.7 \\
\hline 8. & Meschede et al. $^{37}$ & 1998 & 432 & 436 & 2.1 & 5.5 \\
\hline 9. & Scholtes et al. $^{39}$ & 1998 & 1116 & 1164 & 4.5 & \\
\hline 10. & Tuerlings et al. $^{39}$ & 1998 & 1792 & -- & 4.0 & 9.8 \\
\hline 11. & Van der Ven et al. $^{40}$ & 1998 & 305 & 305 & 3.3 & -- \\
\hline 12. & Peschka et al. $^{41}$ & 1999 & 781 & 781 & 2.6 & 3.3 \\
\hline 13. & Gekae et al. $^{42}$ & 2001 & 2196 & 1012 & 6.1 & 5.8 \\
\hline
\end{tabular}


The Cytogenetic Basis of Human Infertility: A Review

\begin{tabular}{|l|l|l|l|l|l|l|}
\hline 14. & Alkhalaf et al. $^{43}$ & 2002 & 118 & -- & 10.16 & -- \\
\hline 15. & Carp et al. $^{44}$ & 2004 & 458 & -- & 9.60 & -- \\
\hline 16. & Quilter $^{45}$ & 2005 & 103 & -- & 9.7 & - \\
\hline 17. & Lissitsina et al. $^{1}$ & 2006 & 27 & -- & 18.5 & -- \\
\hline 18. & Gagare et al. $^{46}$ & 2012 & 112 & -- & 11.6 & -- \\
\hline 19. & Drugkar et al. $^{47}$ & 2013 & 70 & -- & 12.85 & -- \\
\hline
\end{tabular}

\section{Microdeletion of $Y$ chromosome:}

The variation of $Y$ chromosome size in human is well known and there have been studies on the correlation of $Y$ chromosome size with mental state, behavioral disorders and miscarriage ${ }^{48}$.

Debraekeleer and Dao had reviewed several series reported on the type and the frequencies of chromosome abnormalities based on the type of male infertility problems. They also provided data on the relationship between meiotic abnormalities and male infertility ${ }^{15}$. The underlying genetic basis of male infertility remains largely unknown. It has been reported that $13.7 \%$ of azoospermia males and $4.6 \%$ of severe oligozoospermic males have abnormal karyotype ${ }^{49}$. Genes located on the long arm of Y chromosome of men are likely to be involved in the complex process of spermatogenesis ${ }^{50}$.

Azoospermic factor (AZF) due to microdeletion of the long arm of the human Y chromosome involving three regions is associated with complete absence of spermatozoa or reduced sperm count ${ }^{51}$.

Table II: AZF gene region and their phenotype.

\begin{tabular}{|c|c|c|c|}
\hline S. No. & Gene region & Candidate genes & Phenotype \\
\hline 1 & AZFa & USP9Y & Absence of germ cells, aka sertoli cell only syndrome (SCOS) \\
\hline 2 & DBY & EIF1AY & Maturation arrest at spermatocyte stage \\
& & RBMY & \\
\hline 3 & AZFc & DAYA1) & Variable from SCOS to severe oligospermia \\
& & CDY1 & \\
& & BPY2 & \\
& & PRY & \\
& & TTY2 & \\
\hline
\end{tabular}

The frequency of $Y$ chromosome structural rearrangements was found to be higher than the frequency observed in newborn series. Much has been said on the possible deleterious effects of short and long $\mathrm{Y}$ chromosome $\left(\mathrm{Yq}^{-}\right.$and $\left.\mathrm{Yq}^{+}\right)$but no definite conclusions were drawn ${ }^{52}$. These rearrangements were preferentially seen in azoospermia and severe oligozoospermia (Sperm count $<10 \times 10^{6} / \mathrm{ml}$ ) exhibiting 1 and $0.6 \%$ respectively. A few cases of $\mathrm{Y}$ chromosome structural rearrangements involved failure of pairing between the $\mathrm{X}$ and $\mathrm{Y}$ chromosomes. These include a dicentric $\mathrm{Y}$ chromosome and a pericentric inversion of the $\mathrm{Y}$ chromosome. Several oligozoospermic males were found to have a deletion of the long arm of the $\mathrm{Y}$ chromosome ${ }^{53,54}$.

Table III: Y chromosome microdeletion in different infertile males.

\begin{tabular}{|c|c|c|c|c|c|}
\hline $\begin{array}{l}\text { S. } \\
\text { No. }\end{array}$ & Author & Year & No. of patients & $\begin{array}{c}\text { No. of deleted } \\
\text { patients }\end{array}$ & $\begin{array}{c}\text { Microdeletion } \\
(\%)\end{array}$ \\
\hline 1. & Tse et al. $^{55}$ & 2000 & 58 & 4 & 6.90 \\
\hline 2. & Tzschach et al. $^{56}$ & 2001 & 97 & 0 & 0.00 \\
\hline 3. & Peterlin et al. ${ }^{57}$ & 2002 & 226 & 10 & 4.42 \\
\hline 4. & Dada et al. $^{58}$ & 2003 & 83 & 8 & 9.64 \\
\hline 5. & Athalye et al. ${ }^{59}$ & 2004 & 100 & 12 & 12 \\
\hline 6. & Medica et al. ${ }^{60}$ & 2005 & 105 & 1 & 0.95 \\
\hline 7. & Hsu et al. ${ }^{61}$ & 2006 & 460 & 24 & 5.22 \\
\hline 8. & Mohammed et al. ${ }^{62}$ & 2007 & 266 & 7 & 2.63 \\
\hline 9. & Balkan et al. $^{63}$ & 2008 & 80 & 1 & 1.25 \\
\hline 10. & Ceylan et al. $^{64}$ & 2009 & 90 & 11 & 12.22 \\
\hline 11. & Stahl et al. ${ }^{65}$ & 2010 & 1591 & 149 & 9.37 \\
\hline 12. & Behulova et al. $^{66}$ & 2011 & 226 & 8 & 3.54 \\
\hline 13. & Kim et al. ${ }^{67}$ & 2012 & 1306 & 101 & 7.73 \\
\hline 14. & Chellat et al. $^{68}$ & 2013 & 80 & 1 & 1.25 \\
\hline 15. & Omar et al. ${ }^{69}$ & 2014 & 36 & 3 & 8.33 \\
\hline 16. & Yuanyuan et al. $^{70}$ & 2014 & 1218 & 105 & 8.62 \\
\hline
\end{tabular}

\section{Syndromes}

Many genetic syndromes associated with infertility in humans, such as Noonan syndrome, immotile cilia syndrome, Kallmann syndrome, Androgen insensitivity syndrome, polycystic kidney diseases, ushers syndrome etc. 
Table IV: Some genetic syndromes associated with infertility.

\begin{tabular}{|c|c|c|c|c|c|}
\hline $\begin{array}{l}\text { S. } \\
\text { No. }\end{array}$ & Genetic syndrome & Incidence & Inheritance & Features & Reference \\
\hline 1. & $\begin{array}{l}\text { Androgen insensitivity } \\
\text { syndrome }\end{array}$ & $1: 60,000$ & $\begin{array}{l}\text { X linked recessive } \\
\text { syndrome }\end{array}$ & $\begin{array}{l}\text { Mild spermatogenic defect, present at birth } \\
\text { with ambiguous genitalia and signs of both } \\
\text { male and female sexual development. } \\
\text { Caused by mutations in AR gene }\end{array}$ & $\begin{array}{l}\text { Patrizio and } \\
\text { Broomfield }^{21}\end{array}$ \\
\hline 2. & $\begin{array}{l}\text { Frasier syndrome and } \\
\text { Denys-Drash } \\
\text { syndrome }\end{array}$ & $1: 10,000$ & $\begin{array}{c}\text { Autosomal } \\
\text { dominant }\end{array}$ & $\begin{array}{l}\text { Renal failure, Wilm's tumor, hypertension, } \\
\text { gonadal dysgenesis. } \\
\text { Caused by mutation in the WT1 gene. }\end{array}$ & $\begin{array}{l}\text { Swain and } \\
\text { Lovell- } \\
\text { Badge }^{71}\end{array}$ \\
\hline 3. & Kallmann syndrome & $\begin{array}{l}1: 10,000- \\
60,000\end{array}$ & $\begin{array}{l}\text { X linked, } \\
\text { Autosomal } \\
\text { dominant }\end{array}$ & $\begin{array}{l}\text { Delayed or absent puberty and an impaired } \\
\text { sense of smell. } \\
\text { Caused by mutation in the KALIG-1 gene. }\end{array}$ & $\begin{array}{l}\text { Nudell and } \\
\text { Turek }^{72}\end{array}$ \\
\hline 4. & Noonan syndrome & $1: 1000-2500$ & $\begin{array}{c}\text { Autosomal } \\
\text { dominant }\end{array}$ & $\begin{array}{l}\text { Congenital heart defect, hypertrophic } \\
\text { cardiomyopathy, short stature, learning } \\
\text { problems, pectus excavatum, webbed nack } \\
\text { and flat nose bridge. } \\
\text { Caused by mutation in the PTPN11 gene. }\end{array}$ & $\begin{array}{l}\text { Tartaglia et } \\
\text { al. }^{73}\end{array}$ \\
\hline 5. & $\begin{array}{l}\text { Polycystic kidney } \\
\text { disease }\end{array}$ & $1: 800$ & $\begin{array}{c}\text { Autosomal } \\
\text { dominant }\end{array}$ & $\begin{array}{l}\text { Progressive cyst development and } \\
\text { bilaterally enlarged kidneys with multiple } \\
\text { cysts. } \\
\text { Caused by mutations in the PKD1, PKD2 } \\
\text { and PKHD1 genes. }\end{array}$ & $\begin{array}{l}\text { Patrizio and } \\
\text { Broomfield }^{21}\end{array}$ \\
\hline 6. & Ushers syndrome & $1: 30,000$ & $\begin{array}{l}\text { Autosomal } \\
\text { recessive }\end{array}$ & $\begin{array}{l}\text { Combination of hearing loss and visual } \\
\text { impairment, leading cause of deaf-blindness } \\
\text { and degeneration of the sperm axoneme. } \\
\text { Caused by mutations in the CDH23, } \\
\text { MYO7A, PCDH15, USH1C, USH2A, } \\
\text { GPR98 genes. }\end{array}$ & $\begin{array}{l}\text { Patrizio and } \\
\text { Broomfield }^{21}\end{array}$ \\
\hline
\end{tabular}

\section{Conclusions}

Infertility is multi-factorial, but primarily it is because of male factors, female factors or a combination of both. Chromosomal anomalies in infertile subjects may be numerical and structural aberrations. Infertility resulting in men has evoked considerable legal, medical and social interests. Currently, the strongest known genetic marker for infertility leading to violent attitude in some men is the $\mathrm{Y}$ chromosome. Genetic research on this disorder aims at correlating phenotype and genotype. The elucidation of such correlations helps us to achieve a more thorough understanding of infertility in couples. The meaningful genotype-phenotype correlation can only image if sufficient attention is paid to sound documentation of the genotype and consequent clinical phenotype.

The underlying genetic basis of infertility remains largely unknown. Cytogenetic studies particularly on sex chromosome with special reference to $\mathrm{Y}$ chromosome in men are required to be explored.

\section{References}

[1]. Lissitsina J, Mikelsaar R, Punab M. Cytogenetic analyses in infertile men. Arch Androl 2006; 52 (2): 91 -95.

[2]. Greenhall E, Vessay M. The prevalence of subfertility: our view of the current confusion and a report of two new studies. Fertil Steril 1990; 54, 978-983.

[3]. Shah K, Sivapalan G, Gibbons N, Tempest H, Griffin DK. The genetic basis of infertility. Hum Reprod 2003; 126 : 12-25.

[4]. World Health Organization (WHO). Current practices and controversies in assisted reproduction. Report of a meeting on "Medical, Ethical and Social aspects of assisted reproduction" Geneva, World Health Organization 2002.

[5]. Dutta S, Guha RA. Clinico- anatomical study on the etiological factors pertaining to primary infertility in females using some common investigative procedures. J Anat Soc India 2007; 56: 114-147.

[6]. World Health Organization. Special Programme of Research, development and Research Training in Human Reproduction. Geneva; World Health Organization $9^{\text {th }} ; 1980$.

[7]. Bang RA, Bang AT, Baitule Y, Choudhary S, Sarmukkadam S, Tale O. High prevalence of gynecological diseases in rural Indian women. Lancet 1989; 1 (8629): 85-88.

[8]. Datta D. Infertility on the rise. India Today 2010; 35 (27): 40-48.

[9]. Uehara S, Hashiyada M, Sato Y, Fujimori K, Kamura K. Preferential X-chromosome inactivation in women with idiopathic recurrent pregnancy loss. Fertil Sterile 2001; 76: 908-914.

[10]. Gianotten J, Lombardi MP, Zwinderman AH, Lilford RJ, Van der Ven F. Idiopathic impaired spermatogenesis: genetic epidemiology is unlikely to provide a short-cut to better understanding. Hum Reprod Update 2004; 10: 533-539.

[11]. Rives N, Joly G, Machy A, Sim'eon N, Leclerc P, Mac'e B. Assessment of sex chromosome aneuploidy in sperm nuclei from 47,XXY and 46,XY/47,XXY males: comparison with fertile and infertile males with normal karyotype. Mol Hum Reprod 2000; (6): $107-112$.

[12]. Mroz K, Carrel L, Hunt PA. Germ cell development in the XXY mouse: evidence that X chromosome reactivation is independent of sexual differentiation. Dev Biol 1999; 207: 229-238.

[13]. Burgoyne PS. The role of sex chromosomes in mammalian germ cell differentiation. Ann Bio Anim Biochim Bio phys 1978; 18: 317-325. 
[14]. Skakkebaek N, Zenthen E, Nielsen J, Yde H. Abnormal spermatogenesis in XYY males: a report on 4 cases ascertainment through a population study. Fertil Steril 1973; 24: 390-395.

[15]. De-Braekeleer M, Dao TN. Cytogenetic studies in male infertility: a review. Hum Reprod 1991; 6 (2): $245-250$.

[16]. Attanasio A, Blank B, Rager K, Gupta D. Effect of human chorionic gonadotropin on the plasma levels of testosterone, estradiol, sex hormone binding globuline and free testosterone in Klinefelter syndrome. Endokrinologie 1982; 80: $129-134$.

[17]. May KM, Jacobs PA, Lee M, Ratcliffe S, Robinson A, Nielsen J, Hassold TJ. The parental origin of the extra X chromosome in 47, XXX females. Am J Hum Genet 1990; 46: 754-761.

[18]. Hassold T, Benham F, Leppert M. Cytogenetic and molecular analysis of sex-chromosome monosomy. Am J Hum Genet 1998; 42: 534-541.

[19]. Jacobs PA, Baikie AG, Court Brown WM, MacGregor TN, Maclean N, Harnden DG. Evidence for the existence of the human super female. Lancet 1959; 274: 423-425.

[20]. Steven L, Gersen MB, Keagle L. The Principles of Clinical Cytogenetics. New Jersey; Humana Press, 1999.

[21]. Patrizio P, Broomfield D. Male Fertility and Infertility. In: Glover T, Barratt C, editors. Cambridge: Cambridge University Press; 1999. p. 164-173.

[22]. Blouin JL, Binkert F. Antonarakis SE. Biparental inheritance of chromosome 21 polymorphic markers indicates that some Robertsonian translocations $\mathrm{t}(21 ; 21)$ occur postzygotically. Am J Med Genet 1994; 49: 363-368.

[23]. Tharapel AT, Tharapel SA, Bannerman RM. Recurrent pregnancy losses and parental chromosome abnormalities: a review. Br J Obstet Gynaecol 1985; 92: 899-914.

[24]. Forejt J, Crosignani PG, Rubin BL, Fraccaro M. X-Y involvement in male sterility caused by autosome trans-locations: ahypothesis. In: Genetic Control of Gamete Production and Function. New York: Academic Press; 1982. p. 261-273.

[25]. Chandley AC. Infertility and chromsomal abnormality. In: Clark JR editors. Reviews of Reproductive Biology. Oxford, Oxford University Press; 1984.

[26]. Luciani JM, Guichaoua MR, Mattei A, Morazzani MR. Pachytene analysis of a man with a 13q;14q translocation and infertility. Cytogenet Cell Genet 1984; 38: 14-22.

[27]. Rosenmann A, Wahrman J, Richler C, Voss R, Persitz A, Goldman B. Meiotic association between the XY chromosomes and unpaired autosomal elements as a cause of human male sterility. Cytogene Cell Genet 1985; 39: 19-29.

[28]. Nemeth AH, Gallen IW, Crocker M, Levy E, Maher E. Klinefelter-like phenotype and primary infertility in a male with a paracentric Xq inversion. J Med Genet 2002; 39: 28.

[29]. Dar H, Tal J, Bar-el H, Halpern I, Sharf M. Paracentric inversion of Xq and ovarian dysfunction. Am J Med Genet 1988; 29: 16770.

[30]. Hens L, Bonduelle M, Liefaers I, et al. chromosome aberrations in 500 couples referred for in-vitro-fertilization or related fertility treatment. Hum Reprod 1988; 3: 451-7.

[31]. Lange R, Michelmann HW, Engel W. Chromosomale Ursachen der Infertilita“t beim Mann. Fertilita“t 1990; 6: 17-28.

[32]. Baschatt AA, Kupker W, Hasani S, Diedrich K, Schwinger E. Results of Cytogenetic analysis in men with severe subfertility pri or to intracytoplasmic sperm injection. Hum Reprod 1996; 11 (2): 330-3.

[33]. Peschka B, Schwanitz G, Van der Ven K. Type and frequency of constitutional chromosome aberrations in couples undergoing ICSI. Hum Reprod 1996; 11: 222-5.

[34]. Testart J, Gautier E, Brami C, Rolet F, Sedbon E, Thebault A. Intracytoplasmic sperm injection in infertile patients with structural chromosome abnormalities. Hum Reprod 1996; 11 (12): 2609-12.

[35]. Mau UA, Bäckert IT, Kaiser P, Kiesel L. Chromosomal findings in 150 couples referred for genetic counselling prior to intracytoplasmic sperm injection. Hum Reprod 1997; 12: 930-7.

[36]. Montag M, Van der Ven K, Ved S, et al. Success of Intracytoplasmic sperm injection in couples with male and/or female chromosome aberrations. Hum Reprod. 1997; 12, 2635-40.

[37]. Meschede D, Lemcke B, Exeler JR, et al. Chromosome abnormalities in 447 couples undergoing intracytoplasmic sperm injection prevalence, types, sex distribution and reproductive relevance. Hum. Reprod 1998; 13: 576-82.

[38]. Scholtes MC, Behrend C, Dietzel-Dahmen J, et al. chromosomal aberrations in couples undergoing Intracytoplasmic sperm injection: influence on implantation and ongoing pregnancy rates. Feril Steril 1998; 70: 933-7.

[39]. Tuerlings JH, de France HF, et al. Chromosome studies in 1792 males prior to Intracytoplasmic sperm injection: the Dutch experience. Eup J Hum Genet 1998; 6: 194-200.

[40]. Van der Ven K, Peschka B, Monteg M, et al. increased frequency of chromosomal aberrations in female partners of couples undergoing Intracytoplasmic sperm injection. Hum Reprod 1998; 13: 48-54.

[41]. Peschka B, Leygraaf J, Van der Ven K, Montag M, Schartmann B, Schubert R, et al. Type and frequency of chromosome aberration in 781 couples undergoing Intracytoplasmic sperm injection. Hum Reprod 1999; 14: 2257-63.

[42]. Gekas J, Thepot F, Turleau C, et al. Chromosomal factors of infertility in candidate couples for ICSI: an equal risk of constitutional aberrations in women and men. Hum Reprod 2001; 16 (1): 82-90.

[43]. Alkhalaf M, Varghese L, Muharib N. A Cytogenetic study of Kuwaiti couples with infertility and reproductive disorders: short arm deletion of chromosome 21 is associated with male infertility. Annales de Genetique 2002; 45 (3): 147-9.

[44]. Carp H, Feldman B, Oelsner G, Schiff E. Parental karyotype and subsequent live births in recurrent miscarriage. Fertil steril 2004; 81(5): $1296-1301$.

[45]. Quilter C. Chromosomal abnormalities and male infertility. Indian J Med Res 2005; 112: 11-2.

[46]. Gagare DB, Borade NG, Pradhan GC, Daule JP, Patil VV. Male infertility in western region of india: a cytogenetic study of 112 patients with impaired spermatogenesis. Int J Med Res Health Sci, 2012; 1 (1): 20-8.

[47]. Drugkar AZ, Gangane SD, More RM, Drugkar SA. Cytogenetic study in male infertility. IOSR-JDMS 2013; 5 (2): 5-11.

[48]. Verma SR, Huq A, Madahar C, Qazi Q, Dasik H. Higher incidence of small y chromosome in humans with Trisomy 21 (Down syndrome). Pediat Res 1982; 16: 769-70.

[49]. Gunduz G, Luleci G. Benykara M. Cytogenetic study in 102 infertile men. Urol Int 1998; 6: 32-4.

[50]. Ferlin A, Barfora A, Foresta C. Genetic causes of male infertility. Reprod Toxic 2006; 2: 133-41.

[51]. Vogt P, Edelmann A, Kirschs S, Henegariu O, Hirschmann P, Kiesewetter F, et al. Human Y chromosome azoospermia factors (AZF) mapped to different subregions in Yq 11. Hum Genet 1996; 5 (7): 933-43.

[52]. De-Braekeleer M, Dao TN. Cytogenetic studies in couple experimenting repeated pregnancy loss. Hum Reprod 1990; 5: 519-28.

[53]. Neu RL, Barlewo HJ, Gardner LI. A 46, Xyq- male with aspermia. Fertile Sterile 1973; 24: 811-3.

[54]. Tiepolo L, zuffardi O, Fraccaro M, Giarola A. Chromosome abnormalities and male Infertility in Oligozoospermia: Recent progress in Andrology. In: Frajese G, Hafez ESE, Conti C, Fabbrini A. editors. New Yark : Ravan press; 1981. p. 233-45. 
[55]. Tse J, Yeung W, Lau E, Ng E, So W, Ho PC. Deletions within the azoospermia factor subregions of the Y-chromosome in Hong Kong Chinese men with severe male-factor infertility: controlled clinical study. Hong Kong Med J 2000; 6: 143-6.

[56]. Tzschach A, Thamm B, Imthurn B, Weber W, Alexander H, et al. Absence of Yq microdeletions in infertile men. Arch Androl 2001; 47: 167-71.

[57]. Peterlin B, Kunej T, Sinkover J, Gligorievska N, Zorn B. Screening for Y chromosome microdeletions in 226 Slovenian subfertile men. Hum Reprod 2002; 17: 17-24.

[58]. Dada R, Gupta N, Kucheria K. Molecular screening for Yq microdeletion in men with idiopathic oligozoospermia and azoospermia. J Biosci 2003; 28: 163-8.

[59]. Athalye AS, Madon PF, Naik NJ, Naik DJ, Gavas SS, et al. A study of Y chromosome microdeletions in infertile Indian males. Inl J Hum Genet 2004; 4: 179-85.

[60]. Medica I, Gligorievska N, Prenc M, Peterlin B. Y microdeletions in the Istria county, Croatia. Asian J Androl 2005; 7: 213-6.

[61]. Hsu CC, Kuo PL, Chuang L, Lin YH, Teng YN, Lin YM. Uniform deletion junctions of complete azoospermia factor region c deletion in infertile men in Taiwan. Asian J Androl 2006; 8: 205-11.

[62. Mohammed F, Al-Yatama F, Al-Bader M, Tayel SM, Gouda S, Naguib KK. Primary male infertility in Kuwait: a cytogenetic and molecular study of 289 infertile Kuwaiti patients. Andrologia 2007; 39: 87-92.

[63]. Balkan M, Tekes S, Gedik A. Cytogenetic and $\mathrm{Y}$ chromosome microdeletion screening studies in infertile males with Oligozoospermia and Azoospermia in Southeast Turkey. J Assist Reprod Genet 2008; 25: 559-5.

[64]. Ceylan GG, Ceylan C, Elyas H. Genetic anomalies in patients with severe oligozoospermia and azoospermia in eastern Turkey: a prospective study. Genet Mol Res 2009; 8 (3): 915-22.

[65]. Stahl PJ, Masson P, Mielnik A, Marean MB, Schlegel PN, Paduch DA. A decade of experience emphasizes that testing for Y microdeletions is essential in American men with azoospermia and severe oligozoospermia. Fertil Steril. 2010; 94: 1753-6.

[66]. Behulova R, Varga I, Strhakova L, Bozikova A, Gabrikova D, Boronova I, Repiska V. Incidence of microdeletions in the AZF region of the $\mathrm{Y}$ chromosome in Slovak patients with azoospermia. Biomed Pap Med Fac Univ Palacky Olomouc Czech Repub. 2011; 155: 33-8.

[67]. Kim MJ, Choi HW, Park SY, Song IO, Seo JT, Lee HS. Molecular and cytogenetic studies of 101 infertile men with microdeletions of Y chromosome in 1,306 infertile Korean men. J Assist Reprod Genet 2012; 29 (6): 539-46.

[68]. Chellat D, Rezgoune ML, McElreavey K, Kherouatou N, Benbouhadja S, Douadi H, Cherifa B, Abadi N, Satta D. First study of microdeletions in the Y chromosome of Algerian infertile men with idiopathic oligo- or azoospermia. Urol Int. 2013; 90: 455-9.

[69]. Omar FK, Abdulfattah SF, Almuthana AA. Genetic screening for AZF Y chromosome microdeletions in Jordanian azoospermic infertile men. Int J Mol Epidemiol Genet 2014; 5 (1): 47-50.

[70]. Yuanyuan Z, Qiang D, Xiaoliang L, Wanting C, Rong H, Yanyan Z. Screening of azoospermia factor microdeletions on Y chromosome in infertile men by QF-PCR. Yi Chuan. 2014; 36 (6): 552-7.

[71]. Swain A, Lovell-Badge R. Mammalian sex determination: a molecular drama. Genes Dev 1999; 13: $755-67$.

[72]. Nudell DM, Turek PJ. Genetic causes of male infertility: current concepts. Curr Uroly Rep 2000; 1:273-81.

[73]. Tartaglia M, Mehler EL, Goldberg R, et al. Mutations in PTPN11, encoding the protein tyrosine phosphatase SHP-2, cause Noonan syndrome. Nat Genet 2001; 29: 465-8. 